\title{
Dissolved organic carbon-bacteria interactions at sediment-water interface in a tropical mangrove system* $^{*}$
}

\author{
Kevin G. Boto, Daniel M. Alongi, Alan L. J. Nott \\ Australian Institute of Marine Science, PMB No. 3, Townsville MC, Queensland 4810, Australia
}

\begin{abstract}
In order to determine the efficiency of in situ carbon recycling in tropical mangrove sediments, and the contribution of porewater dissolved organic carbon (DOC) to surface-sediment bacterial production, concentrations and fluxes of DOC were measured and compared with simultaneous estimates of bacterial densities, productivity and specific growth rates, in a mangrove forest in Queensland, Australia. The range of interstitial DOC concentrations ( 4 to $50 \mathrm{mgC}^{-1}$ ) was similar to that reported for temperate marine sediments although seasonal variations were much less apparent. Soluble tannins constituted 2 to $51 \%$ of the interstitial DOC pools, which varied significantly with tidal elevation (high $>$ mid $>$ low intertidal) and showed significant variation with sediment depth (to $1 \mathrm{~m}$ ) only in the mid intertidal. Bacterial densities and activity in surface sediments (to $1 \mathrm{~cm}$ ) were high (annual range in productivity: 0.9 to $4.1 \mathrm{gC} \mathrm{m}^{-2} \mathrm{~d}^{-1}$ ), consistent with previous estimates at this site. Surface $(1 \mathrm{~cm}$ depth) sediment DOC concentrations varied with elevation in the intertidal zone $(10$ sites from low to high intertidal), and showed no correspondence with seasonal or spatial variations in bacterial parameters, except for a significant correlation $(r=0.71, n=10)$ between DOC and bacterial growth rate, in austral autumn, for samples throughout the tidal range. Despite the high concentration gradient of DOC between porewaters and overlying tidal waters, significant efflux of DOC was rarely detected unless sediments were poisoned, to $1 \mathrm{~cm}$ depth, with mercury, which resulted in significant and generally high rates of efflux. Efflux rates varied widely with tidal elevation and season (range: 0 to $2.4 \mathrm{gC} \mathrm{m}^{-2} \mathrm{~d}^{-1}$ ). These DOC flux rates provide, on average, $35 \%$ (range: 0 to $100 \%$ ) of bacterial productivity requirements at the sediment-water interface. This study suggests that the mangrove sediments function as an efficient sink for DOC and that its export from the system is minor.
\end{abstract}

\section{INTRODUCTION}

Mangrove forests are an important coastal ecosystem in the Indo-Pacific region, in terms of areal extent, and are considered to play a key role in supporting nearshore fisheries (Odum \& Heald 1975, Boesch \& Turner 1984). This long-accepted dogma was recently subjected to critical scientific examination, at least for the Australian situation, by Robertson \& Duke (1987), who obtained concurrent data on the densities of fish and crustaceans in mangrove and control (non-mangrove) sites. While that study demonstrated the importance of mangroves as a habitat for juvenile fish and crustacean species, it is still unclear whether the mangroves represent a substantial food resource to support coastal food chains. A major objective of our ongoing studies has

\footnotetext{
- AIMS contribution No. 454
}

been to define and investigate the main trophic links within mangroves, including the links between dissolved nutrients and microbiota.

Recent studies (Gillan \& Hogg 1984, Alongi 1988a) have demonstrated very high densities and productivity of bacteria in mangrove sediments of tropical Australia, with abundances commonly exceeding $10^{11}$ cells per $g$ dry wt of sediment, and bacterial production averaging ca $1.6 \mathrm{gC} \mathrm{m}^{-2} \mathrm{~d}^{-1}$ or 2 to 10 times higher than has been reported for other marine sediments (Fallon et al. 1983, Moriarty 1986). Sedimentary bacterial populations in tropical mangroves appear to be controlled mainly by physical factors such as temperature and degree of tidal inundation, with apparently very little consumption by the low meiofaunal populations in these sediments (Alongi 1988a,b).

It is evident that the sedimentary bacteria play a significant role in energy flows and cycles of tropical 
mangroves. They appear to be mainly involved with secondary processing of primary production and possibly act as a 'carbon sink' wherein carbon is efficiently recycled within the sediment and microbial food chains (Alongi 1988b). The 'carbon sink' hypothesis has evolved from observations that (1) seasonal rates of bacterial production (up to $5 \mathrm{gC} \mathrm{m}^{-2} \mathrm{~d}^{-1}$ ) can significantly exceed the highest rates of primary production, and (2) dissolved free amino acids, in the sediment porewaters, are rapidly and completely utilized by microbes at the sediment surface (ca 0 to $1 \mathrm{~cm}$ depth) (Stanley et al. 1987). Amino acid fluxes contribute a substantial proportion (up to $38 \%$ ) of the nitrogen requirements of the sediment surface bacteria but only 5 to $19 \%$ of the carbon requirements. However, amino acids constitute only 1 to $5 \%$ of the sediment dissolved organic carbon (DOC) pool, implying that other components of the DOC flux from below-ground may contribute substantially to the carbon requirements of the highly productive bacterial populations at the sediment-water/air interface.

Very little data on the quantity and role of DOC in marine sediments are available. Recently, the role of DOC in the ocean and its use by pelagic bacteria have been reviewed by Azam \& Cho (1987) who concluded that direct utilization of DOC contributes only about $5 \%$ of the carbon required by the oceanic bacteria. In contrast, recent studies of temperate systems (MeyerReil 1984, Henrichs \& Doyle 1986, Herndl et al. 1987) suggested that the porewater DOC of some marine sediments (with bacterial densities in the order of $10^{9}$ cells $\mathrm{g}^{-1}$ ) may be efficiently and rapidly utilized by the sedimentary bacteria.

It was hypothesized, therefore, that the much higher densities of bacteria in the surface sediments of tropical mangroves (Gillan \& Hogg 1984, Alongi 1988a) act as a very effective sink for the porewater DOC, giving rise to negligible export from the system. This study reports on the DOC concentrations found in the porewaters of tropical mangrove sediments and their variations with depth, tidal elevation and season. The results of flux chamber experiments, comparing DOC fluxes from untreated and poisoned sediments, are presented. These support the sink hypothesis and demonstrate the significant contribution of porewater DOC to bacterial productivity at the sediment-water/air interface.

\section{METHODS}

Study area. This study was undertaken at Missionary Bay, Hinchinbrook Island $\left(18^{\circ} 13^{\prime} \mathrm{S} ; 146^{\circ} 11^{\prime} \mathrm{E}\right)$ in Queensland, Australia, during the period October 1986 to April 1988. The area is a large $\left(50 \mathrm{~km}^{2}\right)$, deltaic, continuous mangrove forest dissected by 8 large 6 to
$7 \mathrm{~km}$ long, and about $160 \mathrm{~m}$ wide at the mouth) tidal channels. A $360 \mathrm{~m}$ catwaik traverses the intertidal zone between two of the tidal channels and facilitates research within these forests. The mangrove sediments are predominantly fine, well-sorted silts containing 4 to $16 \%$ organic carbon (Boto \& Wellington 1984). The site has been described in detail elsewhere (Boto \& Wellington 1984, Alongi 1988a).

Elevation within the intertidal zone along the catwalk varies from 0.0 to $1.35 \mathrm{~m}$ above Australian High Datum (AHD; ca mean sea level). Sampling areas designated as low, mid, or high intertidal zones were located at elevations of ca $0.1 \mathrm{~m}, 0.9 \mathrm{~m}$ and $1.35 \mathrm{~m}$ AHD.

Sedimentary DOC sampling. In April 1987, sediment cores were taken, at various locations alongside the catwalk, at low tide. Cores of $1 \mathrm{~m}$ depth were taken as previously described (Boto \& Wellington 1984). Further samples for examination of 0 to $10 \mathrm{~cm}$ depth profiles were taken, in June 1987, using aluminium corers of $6 \mathrm{~cm}$ diameter from which $2 \mathrm{~cm}$ depth interval sections were cut. In April and October 1987, surface (0 to $2 \mathrm{~cm}$ ) sections were taken as required, using aluminium rings of the same size, by carefully pushing into the sediment and then digging out intact.

All samples for DOC analysis in this study were obtained by filtration through $0.4 \mu \mathrm{m}$ membrane filters. Trial filtrations, of bacterial cultures, carried out in our laboratories (Alongi unpubl.), have demonstrated that at least $70 \%$ of the total bacteria were retained on $0.4 \mu \mathrm{m}$ filters. Use of $0.2 \mu \mathrm{m}$ pore size filters is generally not practical owing to the resulting extremely slow filtration rates of the mangrove waters which contain considerable quantities of suspended clay. The use of the larger pore size therefore was a compromise between a slightly reduced efficiency of bacterial filtration and a greatly increased filtration time. In addition, the lack of correlation between DOC in pore waters obtained through $0.4 \mu \mathrm{m}$ filtration and total sedimentary bacterial numbers (see 'Results') provides further evidence that this technique effectively excludes most bacteria from the DOC samples.

Porewaters were extracted using a modified version of the teflon pore water squeezers previously described (Robbins \& Gustinis 1976, Stanley et al. 1987). Samples were acidified to $\mathrm{pH} 2$ and stored at 2 to $5^{\circ} \mathrm{C}$ until analysis. The design of the squeezers and the use of applied nitrogen gas pressure of only $100 \mathrm{kPa}$ minimizes changes to the anaerobic pore waters and virtually eliminates potential contributions from lysed bacterial cells (Stanley et al. 1987).

Although a previous study (Stanley et al. 1987) demonstrated the lack of any measurable effect on dissolved free amino acids through squeezing of roots, a further experiment was carried out in this study to demonstrate that total DOC extracted from the sediments was simi- 
larly unaffected. After squeezing, surface sediment samples ( 0 to $2 \mathrm{~cm}$ depth, $n=20$ ) were washed and sieved (63 $4 \mathrm{~m}$ mesh) to separate the fine root material. The resulting correlation between porewater DOC concentration and dry weight of root material in each sample was not statistically significant $(r=-0.08, n=20)$ indicating that it is unlikely there was contamination of the DOC from squeezing of roots or root hairs

Flux chamber experiments. These were carried out using $1 \mathrm{l}$ glass chambers with a sediment surface area of $0.007 \mathrm{~m}^{2}$. Each chamber was fitted with an electric motor/propellor assembly, encased in a waterproof housing, to provide constant stirring. At each low, mid and high intertidal location, 6 chambers were positioned randomly and inserted into the sediments at low tide, to a depth such that the remaining chamber volume was $500 \mathrm{ml}$. About $0.5 \mathrm{~h}$ before tidal waters covered the chambers, $20 \mathrm{ml}$ of $5 \%$ mercuric chloride solution was added, via syringe, to the sediment surface in 3 of the chambers, to completely stop bacterial activity in the surface sediments. Once the chambers were filled with incoming tidal water, the stirring speed employed represented a compromise between efficient stirring for representative sampling, and the necessity to ensure that the sediment surface was not disturbed.

Samples were withdrawn from each chamber at intervals of 30 to $45 \mathrm{~min}$ until the tide had ebbed sufficiently to uncover the chambers (usually about $3 \mathrm{~h}$ ). At each sampling time, an initial $3 \mathrm{ml}$ sample was discarded and an additional $5 \mathrm{ml}$ sample was filtered through a $0.4 \mu \mathrm{m}$ pre-rinsed Nucleopore filter, acidified to $\mathrm{pH} 2$, and stored at 2 to $5^{\circ} \mathrm{C}$ until analysis. A screw cap on another side arm was loosened sufficiently to allow exchange of water from outside the chamber to prevent the enhanced flux of sediment porewaters into the chambers during sample withdrawal. The slight dilution effect from ingress of tidal water during sampling was considered negligible.

During one sampling period the sediments in the poisoned chambers at all 3 intertidal locations were carefully depth-sectioned at the end of each experiment to determine the maximum depth the mercury penetrated. In the 9 chamber samples examined ( 3 from each intertidal site), the mercury was found to have penetrated to (and was presumed therefore to effectively poison bacteria within) a depth of $1 \mathrm{~cm}$. Hence, flux rates were compared with bacterial production for the top $1.0 \mathrm{~cm}$ of the sediment. It was highly likely that some $\mathrm{HgCl}_{2}$ diffused from the sediments into the flux chamber water during the course of these experiments. This would have tended to increase the apparent flux rate of DOC from the sediments by preventing bacterial utilization in the chamber water. We considered that this effect was negligible, however, owing to the very large differences between bacterial
Table 1. (a) Comparison of DOC concentrations for single 0.4 um-filtered water samples from untreated and poisoned (with $\mathrm{HgCl}_{2}$ ) bacterial cultures containing ca $10^{10}$ cells ml-1

\begin{tabular}{|ccc|}
\hline $\begin{array}{c}\text { Time after } \\
\text { poisoning }(\mathrm{h})\end{array}$ & \multicolumn{2}{c|}{ DOC $\left(\mathrm{mgC}^{-1}\right)$} \\
Untreated & Poisoned \\
\hline 0 & 741 & 688 \\
1 & 708 & 719 \\
2 & 717 & 741 \\
3 & 734 & 699 \\
4 & 680 & 667 \\
\hline
\end{tabular}

(b) DOC concentration of untreated and poisoned (with $\mathrm{HgCl}_{2}$ ) mangrove sediment porewates. Values are means ( \pm 1 $\mathrm{SD)}$ for 3 replicate samples

\begin{tabular}{|ccc|}
\hline $\begin{array}{c}\text { Time after } \\
\text { poisoning }(\mathrm{h})\end{array}$ & \multicolumn{2}{c|}{ DOC $\left(\mathrm{mgC} \mathrm{l}^{-1}\right)$} \\
& Untreated & Poisoned \\
\hline 0.25 & $43.4( \pm 2.7)$ & $35.8( \pm 5.5)$ \\
1 & $30.1( \pm 4.1)$ & $38.3( \pm 6.4)$ \\
2 & $44.4( \pm 11.7)$ & $71.9( \pm 10.7)$ \\
\hline
\end{tabular}

densities in the surface sediments and the overlying waters $\left(>10^{10}\right.$ vs $<10^{8}$ cells $\mathrm{ml}^{-1}$ ).

Two experiments were conducted to determine whether the use of mercuric chloride as a poisoning agent resulted in significant lysing of bacterial cells which could in turn affect the DOC pool in, and the measured efflux rate from, the sediments. In the first experiment, two $250 \mathrm{ml}$ Erlenmeyer flasks, each containing $100 \mathrm{ml}$ of $0.22 \mu \mathrm{m}$-filtered seawater, were inoculated with $5 \mathrm{ml}$ of a stock suspension of bacteria $\left(10^{9}\right.$ cells $\mathrm{ml}^{-1}$ ) grown on 2216 agar medium (Zobell 1941). After incubation for 12 to $16 \mathrm{~h}$ at $20^{\circ} \mathrm{C}$, bacterial densities in each flask increased to $10^{10}$ cells $\mathrm{ml}^{-1}$, similar to the levels found in mangrove sediments. Mercuric chloride solution was added (at dosage rates equivalent to those used in the flux chamber studies) to one of the cultures, while the other was left untreated. Water samples $(5 \mathrm{ml})$ were taken from each flask immediately following the poisoning and at $1 \mathrm{~h}$ periods up to $4 \mathrm{~h}$. The samples were filtered $(0.4 \mu \mathrm{m})$, acidified to $\mathrm{pH} 2$, and stored at $2{ }^{\circ} \mathrm{C}$ until analysis the following day. Mean DOC concentrations in the 2 cultures were not significantly different (Table 1a), and neither showed any consistent variation over the $4 \mathrm{~h}$ period. Results do not suggest any effect of the poisoning treatment on the DOC pool, although it was possible that any such differences may have been masked by the high variability (unexplained) and relatively high concentrations of DOC in these cultures.

The second experiment was carried out using 18 mangrove surface sediment samples $(6 \mathrm{~cm}$ diameter and $2 \mathrm{~cm}$ depth). Mercuric chloride solution (5 $\mathrm{ml}$ of $5 \%$ 
solution) was added immediately to 9 of the samples. After $0.25,1$ and $2 \mathrm{~h}$, pore water samples were squeezed from 3 replicates of each of the poisoned and untreated samples.

No significant change in DOC concentrations in either treatment was evident (Table $1 \mathrm{~b}$ ) up to $1 \mathrm{~h}$, whereas after $2 \mathrm{~h}$ there was a significant increase in the poisoned samples. Owing to the relatively long period before the increase was observed, we consider that the effect was probably not attributable to bacterial lysing

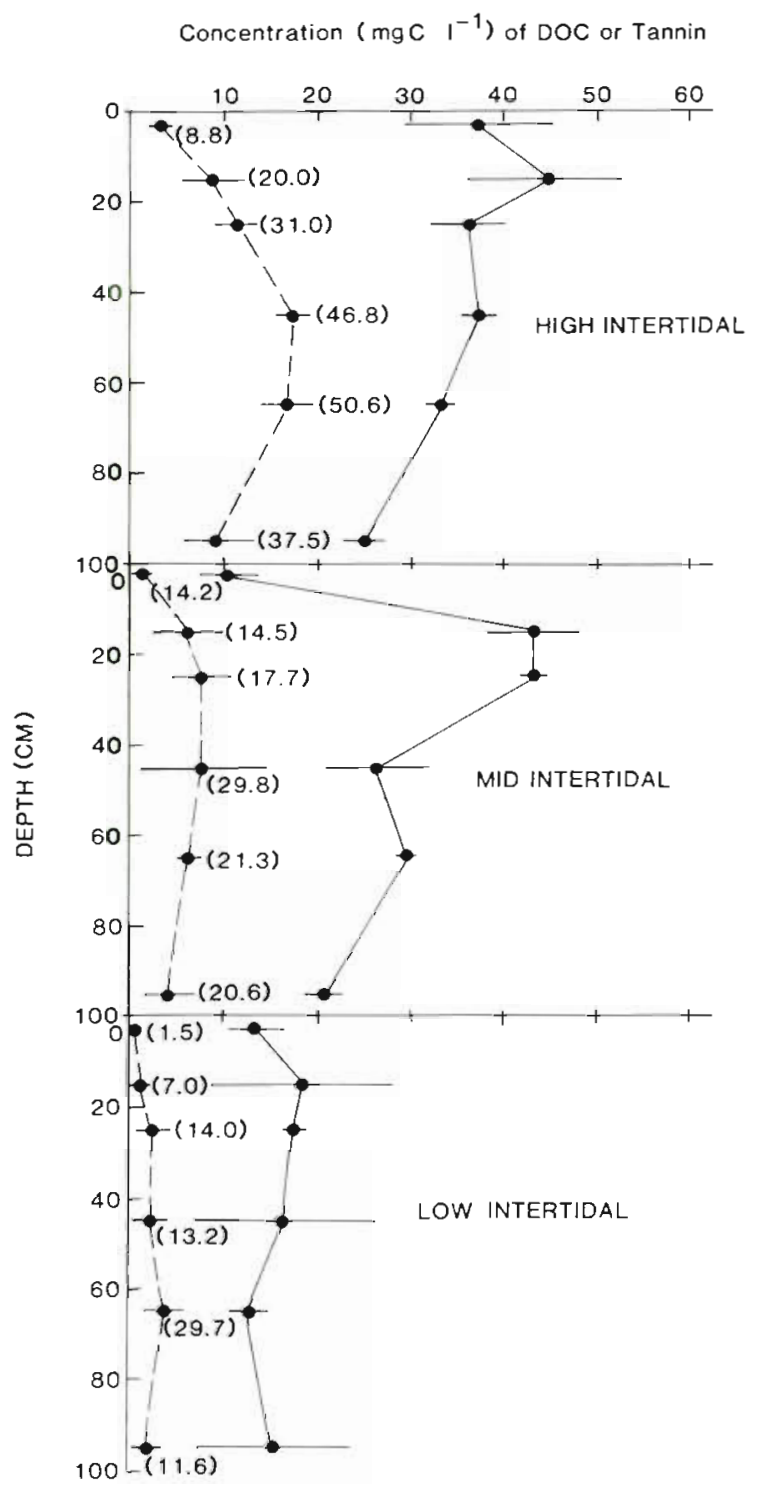

Fig. 1 Variations of porewater DOC (-) and total soluble tannins (- - ) with depth for mangrove sediments at high, mid and low intertidal elevations (see text) along the Coral Creek catwalk transect. Both DOC and tannin concentrations are expressed as mgc $1^{-}$Numbers in parentheses are percentage of tannins in the DOC at each depth. Error bars depict $\pm 1 \mathrm{SD}(n=2$ replicate cores for DOC; $n=3$ replicate cores for tannins) but to some other slower effect such as the degradation of microalgae, protozoa, meiofauna and/or root material following poisoning. It was also probable that such effects were accentuated by the squeezing process used to extract the sample in this experiment. In any case, the effect was not considered to be sufficiently fast or of a magnitude which was iikely to significantly affect the flux chamber experiments which usually ran for a maximum of $3 \mathrm{~h}$. This conclusion was further supported by the observation that even during longer chamber runs, there was never any noticeable increase in DOC efflux rate even after $3 \mathrm{~h}$ (see Fig. 2).

Chemical analyses and bacterial measurements. DOC in the filtered acidified samples was determined, following 5 min sparging with nitrogen to remove inorganic carbon, using a Beckman model TOC analyzer. Analytical precision was typically in the order of \pm 0.2

Table 2. Summary of 2-way ANOVA of data in Fig. 1, examining the variation of sediment DOC, tannins, and proportions of tannin with depth (to $1 \mathrm{~m}$ ) and elevation (high, mid and low intertidal)

(a) DOC ( $n=2$ replicates per cell)

\begin{tabular}{lrrr|}
\hline Source & df & MS & \multicolumn{1}{c|}{$F$} \\
\hline Depth & 5 & 225.4 & $5.57^{\cdots}$ \\
Elevation & 2 & 1229.2 & $30.35^{\cdots}$ \\
Depth $\times$ Elevation & 10 & 98.6 & $2.43^{\circ}$ \\
Error & 18 & 40.5 & \\
\hline
\end{tabular}

(b) Tannins ( $n=3$ replicates per cell)

\begin{tabular}{lrrr|}
\hline Source & df & \multicolumn{1}{c}{ MS } & \multicolumn{1}{c|}{$F$} \\
\hline Depth & 5 & 248.8 & $9.35 \cdots$ \\
Elevation & 2 & 1379.4 & $51.86 \cdots$ \\
Depth $\times$ Elevation & 10 & 62.0 & 2.33 (ns) \\
Error & 36 & 26.6 & \\
\hline
\end{tabular}

(c) Proportions of tannin in the DOC (Fig. 1). The proportion data were arcsin-transformed before analysis. As each proportion is calculated from the mean tannin and DOC values from each cell of (a) and (b), no replication was available and hence Depth $\times$ Elevation interaction is assumed non-significant

\begin{tabular}{|lccc|}
\hline Source & df & MS & $F$ \\
\hline Depth & 5 & 0.03013 & $5.34^{\cdot}$ \\
Elevation & 2 & 0.06536 & $11.58^{\cdots}$ \\
Error & 10 & 0.00564 & \\
ns: non-significant & $(p>0.05) ;$ & $\cdot p<0.05 ;$ & $\cdots p<0.01 ;$ \\
$\cdots p<0.001$ & & & \\
\hline
\end{tabular}


mgC ${ }^{-1}$. The concentration of total soluble tannins was determined using the method of Allen et al. (1974).

Bacterial numbers and productivity were measured as described in detail previously (Alongi 1988a). Briefly, bacterial numbers ( $1 \mathrm{~cm}$ depth) were estimated from replicate core samples at each site $(0.2 \mathrm{~g}$ dry wt sediment core $\left.^{-1}, n=3\right)$ using epifluorescence microscopy (Hobbie et al. 1977). A value of $1.7 \times 10^{-14} \mathrm{gC} \mathrm{cell}^{-1}$ was used to convert bacterial numbers to carbon (Rublee 1982, Gillan \& Hogg 1984). Bacterial production was measured by the rate of $\left[{ }^{3} \mathrm{H}\right.$-methyl]thymidine incorporation into DNA (Pollard \& Moriarty 1984, Alongi 1988a) from 9 replicate sediment cores (each $0.38 \mathrm{~cm}^{3}$ ). Specific growth rate $(\mu)$ of bacteria $\left(\mathrm{d}^{-1}\right)$ was calculated by dividing the mean $(n=9)$ bacterial production estimate ( $\mathrm{mgC} \mathrm{m}^{-2} \mathrm{~d}^{-1}$ ) by the mean $(n=3)$ direct count standing crop estimate $\left(\mathrm{mgC} \mathrm{m}^{-2}\right)$ for each site.

Data analysis. Comparisons of chemical concentration data and bacterial parameters over depth, position within the intertidal zone, or time, were carried out using standard analysis of variance (ANOVA) techniques. Each ANOVA was followed by a StudentNewman-Keuls (SNK) multiple comparisons test if a significant $(p<0.05)$ spatial or temporal effect was found. An $F_{\max }$ test was used before each ANOVA to establish homogeneity of variance of the data. Flux rates were determined by the slope of the linear regression (multiple $Y$ values; $n=3$ for each time period) fitted to the concentration-time data, for those cases where the linear regression was statistically significant at $p<0.05$. Otherwise the net flux, over the time period of the flux experiment, was recorded as non-significant. All statistical analyses were carried out as described by Sokal \& Rohlf (1981).

\section{RESULTS AND DISCUSSION}

\section{DOC variation with depth and position in the intertidal zone}

Sediment porewater DOC concentrations varied significantly with depth (to $100 \mathrm{~cm}$ ) and elevation within the intertidal zone, with concentrations generally increasing with increasing tidal elevation (Fig. 1; Table 2a). Variations of DOC concentration with sediment depth were different at each of the intertidal zones. For example, at the high and low intertidal sites there was no significant variation of DOC with depth except for a significant decrease for the 90 to $100 \mathrm{~cm}$ sample at the high intertidal, while the mid intertidal site showed a distinct and significant maximum between 10 and $30 \mathrm{~cm}$ depth

The samples had a pronounced yellow to orange color owing to the presence of soluble tannins which often accounted for a high proportion of the DOC, ranging from 1.5 to $50.6 \%$ (Fig. 1). The presence of considerable quantities of tannin is due to the Rhizophora spp. which dominate the mangrove tree species in this forest, and which are well-known and traditional sources of tannin (Aksornkae 1987).

Tannin concentrations, like total DOC, varied significantly with depth and elevation within the intertidal zone (Table 2b). The proportion of tannin (as carbon) in the DOC, derived from the mean tannin and DOC concentrations, varied significantly and substantially with depth at each elevation within the intertidal zone, with a maximum between 40 and $70 \mathrm{~cm}$ depth (Fig. 1; Table $2 \mathrm{c}$ ). In the high intertidal site, for example, the tannin proportion ranged from a low of $8.8 \%$ near the surface to a maximum of $50.6 \%$ at the 60 to $70 \mathrm{~cm}$ depth segment. This depth profile contrasts sharply with the depth profile for total DOC and does not correspond with the depth distribution of root material (Boto \& Wellington 1984 and unpubl.) which shows a pronounced maximum between 5 to $30 \mathrm{~cm}$ depth. The deep maxima of tannin concentrations is considered to arise through diffusion along a concentration gradient both towards the surface and towards the deeper sediments from the point of expected tannin production ( 5 to $30 \mathrm{~cm}$ depth). The tannin which diffuses towards the surface, however, appears to be rapidly utilized by bacteria in this zone as evidenced by a rapid decrease in both the concentration and proportion of tannins in the total DOC. The apparent utilization of tannin by the bacteria in the surface zone contrasts sharply with the detrimental (and apparently controlling) effect of these mangrove-derived tannins on the meiofauna in these forests (Alongi 1987).

DOC and bacteria. The variation of DOC in relation to bacterial numbers, productivity and growth rates with depth, at the low, mid, and high intertidal sites (Table $3 a$ ) was examined, at $2 \mathrm{~cm}$ intervals, over the top $10 \mathrm{~cm}$ of the sediment, the zone of highest bacterial activity (Alongi 1988a). The DOC concentrations did not vary significantly with depth over this range, although there was a highly significant variation with elevation $($ high $>$ mid $=$ low; Table $3 b$ )

The correlations between DOC concentrations and bacterial parameters were generally very low and not significant, although there was a significant correlation between DOC and bacterial growth over the $10 \mathrm{~cm}$ depth profile at the low intertidal site $(r=0.95, n=5)$. There was also a weak, but significant, correlation between DOC and bacterial production for the combined data set $(r=0.54, n=15)$.

Because the number of initial data sets $(n=3)$ was too small to test properly for a correlation between mean DOC concentrations (averaged over the $10 \mathrm{~cm}$ depth profile) at each elevation and the corresponding mean bacterial parameters, a further sampling was conducted. Three replicate samples were taken of sur- 
Table 3. (a) Variation of sediment DOC, bacterial density, productivity and growth rate with depth (to $10 \mathrm{~cm}, 2 \mathrm{~cm}$ intervals) and tidal elevation (high, mid and low). Each value is a mean ( $\pm \mathrm{SD}$ ) derived from $n$ replicates. For DOC: $n=3$; bacterial density: $n=$ 3; productivity: $n=9$. Growth rate is a single value derived from the mean values for bacterial productivity and density. Units: DOC, $\mathrm{mgCl}^{-1}$; bacterial density cells $\times 10^{10} \mathrm{~g}^{-1}$ (dry wt); productivity, $\mathrm{gC} \mathrm{m}^{-2} \mathrm{~d}^{-1}$; growth rate, $\mathrm{d}^{-1}$

\begin{tabular}{|c|c|c|c|c|c|}
\hline Tidal elevation & Depth & $\mathrm{DOC}$ & $\begin{array}{c}\text { Bacterial } \\
\text { density }\end{array}$ & Productivity & Growth rate \\
\hline High & $\begin{array}{l}0-2 \\
2-4 \\
4-6 \\
6-8 \\
6-10\end{array}$ & $\begin{array}{l}19.5(1.7) \\
28.8(4.6) \\
38.6(15.6) \\
81.3(78.0) \\
59.0(16.0)\end{array}$ & $\begin{array}{r}49.0(3.0) \\
6.7(3.0) \\
5.3(2.1) \\
3.7(1.9) \\
2.6(1.6)\end{array}$ & $\begin{array}{ll}7.8 & (1.2) \\
7.1 & (0.8) \\
6.8 & (2.1) \\
6.2 & (0.8) \\
4.9 & (0.6)\end{array}$ & $\begin{array}{l}0.83 \\
0.55 \\
0.67 \\
0.87 \\
0.98\end{array}$ \\
\hline Mid & $\begin{array}{l}0-2 \\
2-4 \\
4-6 \\
6-8 \\
8-10\end{array}$ & $\begin{array}{l}10.5(4.2) \\
12.0(4.4) \\
12.7(9.0) \\
15.4(9.8) \\
18.5(5.5)\end{array}$ & $\begin{array}{ll}7.3 & (1.4) \\
2.7 & (0.4) \\
1.8 & (0.3) \\
1.3 & (0.6) \\
2.4 & (0.7)\end{array}$ & $\begin{array}{ll}1.4 & (1.1) \\
1.5 & (0.5) \\
2.8 & (0.1) \\
2.4 & (0.7) \\
3.2 & (1.0)\end{array}$ & $\begin{array}{l}0.17 \\
0.49 \\
1.4 \\
1.6 \\
1.2\end{array}$ \\
\hline Low & $\begin{array}{l}0-2 \\
2-4 \\
4-6 \\
6-8 \\
8-10\end{array}$ & $\begin{array}{l}11.7(7.6) \\
11.0(3.1) \\
14.9(10.1) \\
19.1 \quad(14.4) \\
31.9(6.9)\end{array}$ & $\begin{aligned} 12.0 & (3.0) \\
4.5 & (0.6) \\
5.6 & (1.2) \\
2.9 & (0.5) \\
1.1 & (0.3)\end{aligned}$ & $\begin{array}{ll}2.8 & (1.2) \\
2.7 & (1.4) \\
3.1 & (0.8) \\
1.9 & (0.3) \\
2.1 & (0.6)\end{array}$ & $\begin{array}{l}0.16 \\
0.40 \\
0.37 \\
0.43 \\
1.3\end{array}$ \\
\hline
\end{tabular}

(b) Summary of 2-way ANOVA for DOC data in (a)

\begin{tabular}{|c|c|c|c|}
\hline Source & $\mathrm{df}$ & MS & $F$ \\
\hline Depth & 4 & 837 & 1.84 (ns) \\
\hline Elevation & 2 & 4125 & $9.04 \cdots$ \\
\hline Depth $\times$ Elevation & 8 & 435 & 0.95 (ns) \\
\hline Error & 30 & 456 & \\
\hline \multicolumn{4}{|c|}{ ns: not significant $(p<0.05) ; \cdots p<0.001$} \\
\hline
\end{tabular}

face sediments (top $1 \mathrm{~cm}$ ) at 10 approximately equally spaced intervals along the catwalk transect from low to high intertidal, i.e. at 10 different tidal elevations. This test was carried out in austral autumn (April) and spring (October), 1987, in order to determine seasonal variations in surface sediment DOC concentrations. A 2 -way analysis of variance showed a significant ( $p$ $<0.001$ ) elevation $\times$ season interaction for DOC as well as significant main factors (Table $4 \mathrm{a}, \mathrm{b}$ ). In April, DOC concentrations generally did not change significantly with increasing elevation within the intertidal zone except for the 3 highest elevation sites where a sharp and significant increase was observed. The elevation at Site 8 is very close to the level of mean high water springs (ca $1.3 \mathrm{~m}$ above mean sea level). The infrequent tidal flushing which occurs above this level, with the resulting stagnation of sediment porewaters and a consistently higher degree of anaerobiosis (Boto \& Wellington 1984), is very likely to be the primary cause of the increased DOC at these high intertidal sites.

In October, the highest DOC concentrations were again found at the highest elevation sites. However, the low intertidal sediments (Sites 1,2 and 3) had significantly higher DOC concentrations than were recorded in April whereas the mid-intertidal sites 44,5 and 6) showed no significant changes from April.

The reasons for this seasonal variation in the sedimentary DOC patterns are not readily explained. The DOC variations do not show any apparent relation to the temporal and spatial patterns in bacterial numbers and activity previously reported by Alongi (1988a) at this study site. In addition, there were no significant correlations between DOC and the corresponding bacterial parameters for these sediments (Table 4a), with the exception of a significant $(r=0.71, n=10)$ correlation between DOC and bacterial specific growth rate for the April samples.

The range in porewater DOC concentrations for these tropical mangrove sediments is very similar to that reported for temperate marine sediments (Farke \& Riemann 1980, Hemdl et al. 1987), although seasonal variations in temperate sediment DOC concentrations are generally much greater. Herndl et al. (1987) report highest values of DOC $\left(24 \mathrm{mgC} \mathrm{I}^{-1}\right)$ in September, 
Table 4. (a) Variation of surface sediment (1 cm depth) DOC. bacterial density, productivity and growth rate with tidal elevation ( 10 sites from low to high intertidal) and season (austral autumn and spring). Values shown are means ( \pm 1 SD) derived from $n=3$ replicates for DOC and bacterial density, $n$ $=9$ for productivity. Growth rates are single values derived from mean productivity and mean density values. Units: DOC mgCl ${ }^{-1}$; bacterial density cells $\times 10^{10} \mathrm{~g}^{-1}$ (dry wt); productivity, $\mathrm{gC} \mathrm{m} \mathrm{m}^{-2} \mathrm{~d}^{-1}$; growth rate $\mathrm{d}^{-1}$

\begin{tabular}{|cccccc|}
\hline Season & Site & DOC & $\begin{array}{c}\text { Bacterial } \\
\text { density }\end{array}$ & $\begin{array}{c}\text { Produc- } \\
\text { tivity }\end{array}$ & $\begin{array}{c}\text { Growth } \\
\text { rate }\end{array}$ \\
\hline Austral & 1 & $5.4(1.0)$ & $10.5(1.6)$ & $1.3(0.2)$ & 0.19 \\
autumn & 2 & $6.0(1.5)$ & $14.9(3.3)$ & $3.9(0.4)$ & 0.39 \\
& 3 & $5.8(1.2)$ & $9.8(3.0)$ & $2.4(0.3)$ & 0.36 \\
& 4 & $5.0(0.8)$ & $15.9(3.6)$ & $3.1(0.4)$ & 0.29 \\
& 5 & $4.8(0.5)$ & $18.1(1.9)$ & $5.0(0.5)$ & 0.40 \\
& 6 & $6.9(1.4)$ & $18.5(2.3)$ & $3.7(0.6)$ & 0.30 \\
& 7 & $7.5(2.6)$ & $20.2(10.2)$ & $3.2(0.4)$ & 0.23 \\
& 8 & $11.4(2.7)$ & $13.8(5.1)$ & $3.7(0.8)$ & 0.40 \\
& 9 & $12.0(4.3)$ & $13.7(2.5)$ & $4.3(0.6)$ & 0.46 \\
& 10 & $23.3(2.7)$ & $13.7(3.3)$ & $5.0(1.2)$ & 0.53 \\
Austral & 1 & $11.3(4.2)$ & $4.9(2.5)$ & $1.3(0.2)$ & 0.39 \\
spring & 2 & $11.5(3.2)$ & $3.3(0.4)$ & $1.9(0.2)$ & 0.84 \\
& 3 & $8.3(1.7)$ & $4.2(0.5)$ & $1.5(0.1)$ & 0.52 \\
& 4 & $4.5(0.4)$ & $3.6(0.8)$ & $2.7(0.4)$ & 1.10 \\
& 5 & $4.6(0.6)$ & $3.8(0.8)$ & $2.4(0.4)$ & 0.93 \\
& 6 & $6.8(0.9)$ & $3.6(1.5)$ & $3.3(0.4)$ & 1.30 \\
& 7 & $11.5(1.3)$ & $3.2(1.4)$ & $2.8(0.1)$ & 1.30 \\
& 8 & $11.3(0.3)$ & $3.0(1.4)$ & $2.0(0.2)$ & 0.98 \\
& 9 & $12.0(0.1)$ & $3.0(1.2)$ & $2.2(0.1)$ & 1.10 \\
& 10 & $16.8(1.6)$ & $6.7(1.7)$ & $2.1(0.4)$ & 0.46 \\
\hline
\end{tabular}

(b) Summary of 2-way ANOVA for DOC data in (a)

\begin{tabular}{|crrc|}
\hline Source & df & MS & $F$ \\
\hline Elevation & 9 & 124.95 & $31.92 \cdots$ \\
Season & 1 & 21.06 & $5.37^{\circ}$ \\
Elevation $\times$ season & 9 & 26.47 & $6.75^{*}$ \\
Error & 40 & 3.92 & \\
\hline
\end{tabular}

decreasing steadily to 13 and $6 \mathrm{mgC}^{-1}$ in January and March respectively, for Adriatic Sea surface waters. These authors suggested that the sediment DOC concentrations were linked, at a lag of 2 to $3 \mathrm{mo}$, with seasonal fluctuations in phytoplankton densities. Such a link would be highly unlikely in the tropical mangrove system owing to the much lower densities of benthic microalgae (Alongi 1988a) and phytoplankton (Boto \& Bunt 1981) in this system.

\section{Flux chamber studies}

Preliminary flux chamber studies were carried out, at 3 closely spaced sites, on 3 separate days, in the low intertidal zone in October 1986. Results obtained for the first study (Fig. 2) showed a number of interesting features. The water in untreated chambers showed no significant change in DOC concentrations over a $5 \mathrm{~h}$ period, indicating no net efflux of DOC from the sediments. This was despite substantial concentration gradients between the surface sediment porewaters (ranging from 5 to $40 \mathrm{mgC} \mathrm{l}^{-1}$, depending on position and season) and the overlying water (typically 1 to $2 \mathrm{mgC}$ $1^{-1}$ ). Conversely, chambers where the sediment surface had been poisoned with mercury showed a highly significant (and linear) increase in DOC with time. For the run shown in Fig. 2, the slope of the linear regression was equivalent to a net DOC efflux of $0.91 \mathrm{gC} \mathrm{m}^{-2}$ $\mathrm{d}^{-1}(95 \% \mathrm{CI}= \pm 0.10)$. Results at the 2 other low intertidal sites were similar, with net fluxes of 0.78 $(95 \% \mathrm{Cl}= \pm 0.60)$ and $1.65( \pm 0.56) \mathrm{gC} \mathrm{m}^{-2} \mathrm{~d}^{-1}$ observed for the poisoned chambers only.

These results suggested that the high rates of bacterial growth in the upper few centimetres of the sediments (Alongi 1988a) effectively utilized virtually all of the DOC transported towards the surface via diffusion, convection and advection. The net efflux after poisoning

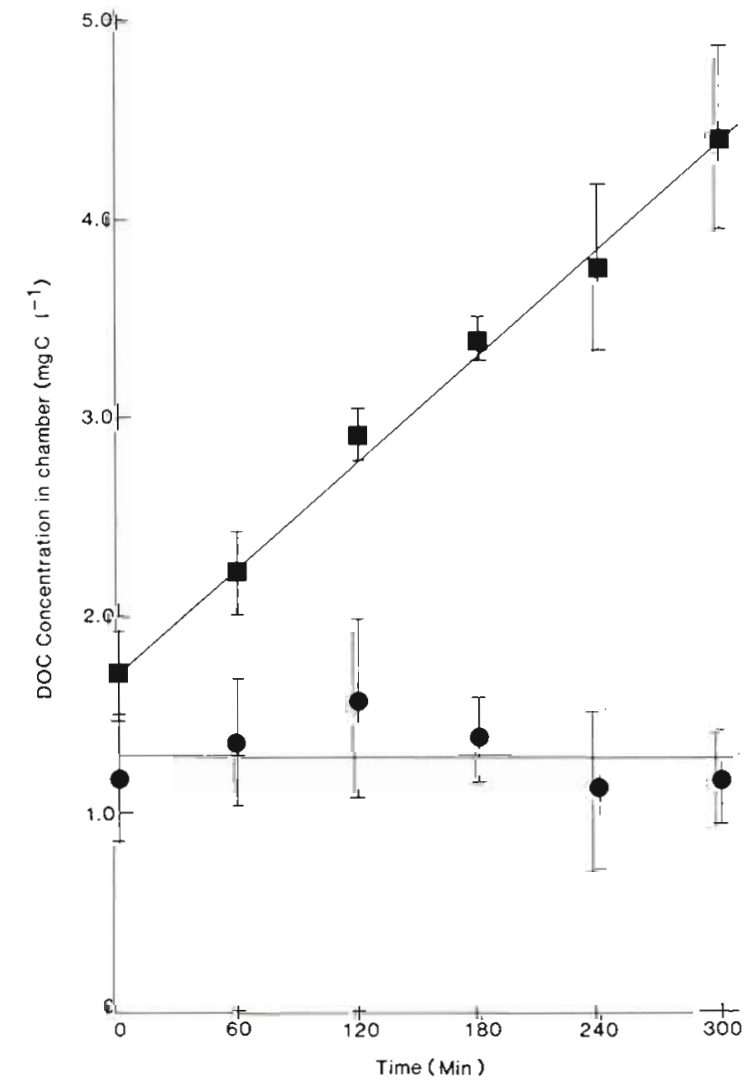

Fig. 2. Variations of DOC concentrations with time, for waters in flux chambers overlying untreated $(\bullet)$ and poisoned (with $\mathrm{HgCl}_{2}$ ) (-) mangrove sediments at the low intertidal site in October 1986. Lines are least squares linear regression fits to the data. Error bars depict $\pm 1 \mathrm{SD}(n=3$ chambers for each treatment) 
Table 5. Rates of DOC efflux ( $\pm 95 \% \mathrm{CI}_{1} n=3$ chambers for each regression) from untreated and poisoned (with $\mathrm{HgCl}_{2}$ ) mangrove sediments, at the times of year and tidal elevations shown. Corresponding rates of surface sediment (1 $\mathrm{cm}$ depth) bacterial productivity ( $\pm 1 \mathrm{SD} ; n=9$ ) are also shown. Units of each: $\mathrm{gC} \mathrm{m}^{-2} \mathrm{~d}^{-1}$

\begin{tabular}{|c|c|c|c|c|c|}
\hline \multirow[t]{2}{*}{ Tidal elevation } & \multirow[t]{2}{*}{ Treatment } & \multicolumn{4}{|c|}{ Time of year } \\
\hline & & April & August & October & December \\
\hline \multirow[t]{3}{*}{ High } & $\mathrm{p}$ & $0.50(0.40)$ & $1.08(0.75)$ & $0.40(0.15)$ & $1.90(0.50)$ \\
\hline & $\mathrm{nt}$ & ns & ns & ns & $0.96(0.35)$ \\
\hline & $\mathrm{BP}=$ & $4.1(1.4)$ & $2.6(0.7)$ & $2.2(0.4)$ & $2.7(0.3)$ \\
\hline \multirow[t]{3}{*}{ Mid } & $\mathrm{p}$ & $0.72(0.50)$ & $0.55(0.40)$ & $0.83(0.12)$ & ns \\
\hline & nt & ns & nS & ns & ns \\
\hline & $\mathrm{BP}=$ & $3.6(0.8)$ & $3.0(1.4)$ & $2.4(0.4)$ & $2.8(0.8)$ \\
\hline \multirow[t]{3}{*}{ Low } & $\mathrm{p}$ & $0.89(0.68)$ & $0.40(0.25)$ & $2.42(0.50)$ & $0.71(0.30)$ \\
\hline & nt & $0.41(0.40)$ & ns & ns & ns \\
\hline & $\mathrm{BP}=$ & $2.5(0.7)$ & $0.9(0.3)$ & $1.9(0.2)$ & $1.9(0.1)$ \\
\hline
\end{tabular}

could therefore be equated to the rate of bacterial utilization of sediment porewater DOC in the upper $1 \mathrm{~cm}$ (the depth to which the influence of mercury poisoning extended). Comparison of the DOC fluxes with previous bacterial production measurements at this site (Alongi 1988a) suggested that the DOC flux could account for up to $40 \%$ of total bacterial production.

Subsequently, bacterial activity in the upper $1 \mathrm{~cm}$ layer of the sediment was also measured at the same locations (high, mid and low intertidal sites) and times (April, August, October and December) as for the flux chamber experiments. Results (Table 5) generally were in good agreement with the preliminary measurements. In only 2 cases was a significant net flux observed for untreated sediments, i.e. at the low intertidal site in April and at the high intertidal site in December. The DOC flux measured after poisoning (equated to the rate of microbial/meiofaunal utilization of the DOC in the upper $1 \mathrm{~cm}$ of the sediment) was, however, usually significantly greater than zero, ranging from 0.4 to $2.4 \mathrm{gC} \mathrm{m}^{-2} \mathrm{~d}^{-1}$.

Seasonal variations in the rates of bacterial productivity were consistent with previous estimates along the catwalk transect (Alongi 1988a). DOC efflux rates, however, did not correlate with bacterial production rates. The proportion of the total bacterial production accounted for by the rate of DOC utilization also varied considerably with time and position. Overall, at the low intertidal site, mean DOC flux accounted for $60 \%$ of the mean total bacterial production, whereas this proportion decreased to 20 and $34 \%$ for the mid and high intertidal sites, respectively. Averaged over all sites and throughout the year, the proportion was $35 \%$.

While DOC efflux from the sediments can account for a substantial proportion of the rates of bacterial production in surface sediments, the contribution is not always sufficiently high to give consistent, significant correlations between the 2 parameters. Nevertheless, the high bacterial populations at the sediment surface appear to act as very efficient interceptors of the DOC efflux from the sediments, thus preventing any export of DOC from mangrove sediments to adjacent tidal waters. These results are consistent with a recent study which showed negligible net annual exchange of DOC to or from the Coral Creek system through tidal transport (Boto \& Wellington 1989).

Previous studies of utilization of DOC by sedimentary bacteria have examined the uptake of added ${ }^{14} \mathrm{C}$ labelled compounds (e.g. Meyer-Reil 1984 and references therein, Henrichs \& Doyle 1986). Another recent study (Herndl et al. 1987) has reported apparent links between seasonal variations in DOC and sediment oxygen demand. While these have provided valuable information on the potential contribution of various components of the DOC pool to the bacterial energy requirements, they do not provide any estimate of actual rates of bacterial utilization of total sedimentary DOC. The present study of tropical mangrove sediments provides the first such quantitative estimate of the role of porewater DOC, and lends some further support to the benthic 'carbon sink' concept (Alongi 1988a,b). Extrapolation of these estimates to other sedimentary systems, however, must be approached with caution because of the very high rates of bacterial productivity in the mangrove sediments and the probable differences in the composition of the porewater DOC (e.g. the high tannin content).

Acknowledgements. We gratefully acknowledge the skilled assistance provided by Frank Tirendi and Bill Burgher who performed the DOC analyses and helped with some of the field sampling 


\section{IITERATURE CITED}

Aksornkae, S. (1987). Traditional uses of the mangrove in Thailand. In: Field, C. D., Dartnall, A. J. (eds.) Mangrove ecosystems of Asia and the Pacific: status, exploitation and management. AIMS and Australian Committee for Mangrove Research, Townsville, Australia, p. 104-113

Alien, S. E., Grimswhaw, H. M., Parkinson, J. A., Quarmby, C. (1974). Chemical analysis of ecological materials. John Wiley and Sons, New York

Alongi, D. M. (1987). The influence of mangrove-derived tannins on intertidal meiobenthos in tropical estuaries. Oecologia (Berl.) 71 : 537-540

Alongi, D. M. (1988a). Bacterial productivity and microbial biomass in tropical mangrove sediments. Microb. Ecol. 15: $59-79$

Alongi, D. M. (1988b). The role of soft-bottom benthic communities in tropical mangrove and coral reef ecosystems. Rev. aquat. Sci. 1: in press

Azam, F., Cho, B. C. (1987). Bacterial utilization of organic matter in the sea. In: Fletcher, M., Gray, T. R. G., Jones, J. G. (eds.) Ecology of microbial communities. Cambridge Univ, Press, Cambridge, p. 261-281

Boesch, D. F., Turner, R. E. (1984). Dependence of fishery species on salt marshes; the role of food and refuge. Estuaries 7: 460-468

Boto, K. G., Wellington, J. T (1984). Soil characteristics and nutrient status in a northern Australian mangrove forest. Estuaries 7: 61-69

Boto, K. G., Wellington, J. T (1989). Seasonal variations in concentrations and fluxes of dissolved organic and inorganic materials in a tropical, tidally-dominated, mangrove waterway. Mar Ecol. Prog. Ser, 50: 151-160

Boto, K. G., Bunt, J. S. (1981). Tidal export of particulate organic matter from a northern Australian mangrove system. Estuar. coast. Shelf. Sci. 13: 247-255

Fallon, R. D., Newell, S. Y., Hopkinson, C. S. (1983). Bacterial production in marine sediments: will cell-specific measures agree with whole system metabolism? Mar. Ecol. Prog. Ser 11. 119-127

Farke, H., Riemann, F. (1980). Dissolved organic carbon in littoral sediments: concentrations and available amounts demonstrated by the percolation method. Veröff. Inst. Meeresforsch. Bremerh. 18: 235-244

Gillan, F. T., Hogg, R. W. (1984). A method for the estimation of bacterial biomass and community structure in man- grove-associated sediments. J. microbiol. Methods 2 275-293

Henrichs, S. M., Doyle, A. P. (1986). Decomposition of ${ }^{14} \mathrm{C}$ labelled organic substances in marine sediments. Limnol. Oceanogr 31: 765-778

Herndl, G. J., Faganeli, J., Fanuko, N., Peduzzi, P., Turk, V (1987). Role of bacteria in the carbon and nitrogen flow between water-column and sediment in a shallow marine bay (Bay of Piran, northern Adriatic Sea). P. S. Z. N. I: Mar Ecol. 8: 221-236

Hobbie, J. E., Daley, R. J., Jasper, S. (1977). Use of Nucleopore filters for counting bacteria by fluorescence microscopy. Appl. environ. Microbiol. 33: 1225-1228

Meyer-Reil, L.-A. (1984). Bacterial biomass and heterotrophic activity in sediments and overlying waters. In: Hobbie, J. E., Williams, P. leB. (eds.) Heterotrophic activity in the sea. NATO Conference Ser. IV: 15. Plenum Press, New York, p. 523-546

Moriarty, D. J. W. (1986). Measurement of bacterial growth rates in aquatic systems from rates of nucleic acid synthesis. Adv. microb. Ecol. 9: 245-292

Odum, W. E., Heald, E. J. (1975). The detritus-based food web of an estuarine mangrove community. In: Cronin, L. E. (ed.) Estuarine research. Academic Press, New York, p. 265-286

Pollard, P. C., Moriarty, D. J. W. (1984). Validity of the tritiated thymidine method for estimating bacterial growth rates: measurement of isotope dilution during DNA synthesis. Appl environ. Microbiol. 48: 1076-1083

Robbins, J. A., Gustinis, J. (1976). A squeezer for efficient extraction of pore water from small volumes of anoxic sediment. Limnol. Oceanogr 21: 905-909

Robertson, A. I., Duke, N. C. (1987). Mangroves as nursery sites: comparisons of the abundance and species composition of fish and crustaceans in mangroves and other nearshore habitats in tropical Australia. Mar. Biol. 96: 193-205

Rublee, P. A. (1982). Bacteria and microbial distribution in estuarine sediments. In: Kennedy, V S. (ed.) Estuarine comparisons. Academic Press, New York, p. 159-182

Sokal, R. R., Rohlf, F. J. (1981). Biometry. The principles and practice of statistics in biological research. W. H. Freeman \& Co., San Francisco

Stanley, S. O., Boto, K. G., Alongi, D. M., Gillan, F. T. (1987) Composition and bacterial utilization of free amino acids in tropical mangrove sediments. Mar. Chem. 22: 13-30

Zobell, C. E. (1941). Studies on marine bacteria. I. The cultural requirements of heterotrophic bacteria. J. mar. Res. 4: 42-75

This article was submitted to the editor; it was accepted for printing on November 4, 1988 